\title{
Kesulitan Pembelajaran Online Mahasiswa Pendidikan Biologi di Tengah Pandemi Covid19
}

\author{
Wiwi Noviati ${ }^{1)^{*}}$ \\ ${ }^{1)}$ Universitas Samawa \\ *wiwinoviati15@gmail.com
}

\begin{abstract}
Abstrak: Universitas Samawa salah satu Lembaga Pendidikan Perguruan Tinggi di Sumbawa sudah menerapkan work from home sesuai aturan yang dikeluarkan pemerintah terkait pandemi covid19. Berbagai strategi yang dilakukan dosen di Universitas Samawa khususnya Fakultas Keguruan dan Ilmu Pendidikan Program Studi Pendidikan Biologi melaksanakan pembelajaran secara online atau online learning. Tujuan penelitian ini untuk mengetahui kesulitan yang dighadapi mahasiswa dalam proses pembelajaran online di tengah pandemic covid19. Penelitian ini menggunakan metode kualitatif deskritif. Teknik pengambilan sampel menggunakan Teknik purposive sampling yaitu mengambil sampel dengan berdasar pada usaha pencapaian tujuan penelitian. Sampel penelitian yaitu mahasiswa Pendidkkan Biologi Universitas Samawa. Teknik pengumpulan data menggunakan kuisioner terkait kesulitan pembelajaran online yang diisi oleh responden. Keabsahan data dalam penelitian ini menggunakan triangulasi. Pada penelitian ini penulis menggunakan triangulasi sumber Sedangkan untuk analisis data dalam penelitian ini menggunakan analisis data model analisis data interaktif. Berdasarkan hasil penelitian bahwa kesulitan mahasiswa melaksanakan proses pembelajaran di tengah pandemi covid19 disebabkan oleh faktor eksternal yaitu sarana prasarana dan sumber daya manusia (ekonomi) dan faktor internal yang berupa minat mahasiswa.
\end{abstract}

Kata Kunci: Kesulitan, Pembelajaran Online, Covid19

\section{Pendahuluan}

Perkembangan zaman di abad 21, membawa dunia Pendidikan harus berkembangan seiring dengan berkembangnya ilmu pengetahuan dan teknologi informasi. Menurut Musliansani, perkembangan teknologi informasi juga didukung oleh adanya teknologi internet yang awalnya dianggap sebagai kebutuhan sekunder, kini telah menjadi teknologi yang sangat dibutuhkan oleh banyak kalangan (Musliansani, 2018). Teknologi informasi sangatlah berdampak pada Pendidikan di Indonesia khususnya, misalnya dalam hal mendapat referensi terbaru dan ter up to date bagi pendidik baik dalam hal materi maupun dalam hal media pembelajaran.

Sekarang ini dunia dihebohkan dengan virus yang mematikan manusia dalam waktu yang cepat dan jumlah yang sangat banyak. Virus ini disebut dengan covid 19. Virus ini merupakan virus RNA strain tunggal positif yang menginfeksi saluran pernapasan (Yuliana, 2020). Hal ini juga berdampak pada dunia Pendidikan karena untuk memutuskan rantai penularan pemerintah negara-negara di dunia memberhentikan aktivitas dan hanya berada di dalam rumah. Di Indonesia akibat dari virus ini sudah mencapai 1.820 orang meninggal dan positif mencapai 23.825 orang. Sedangkan di NTB sendiri yang positif menderita virus ini sudah mencapai 453. Pemerintah sudah melakukan langkah salah satunya memberhentikan proses belajar mengajar di semua Lembaga Pendidikan baik disekolah maupun di perguruan tinggi diganti dengan work from home. Akibat tidak bisa bertatap muka langsung antara pendidik dan peserta didik. Dengan kondisi ini tentunya pendidik harus memiliki kemampuan atau strategi dalam melaksanakan pembelajaran yang dapat meminimalisir kesulitan belajar pada mahasiswa.

Kesulitan belajar merupakan suatu hal yang menyebabkan terhambatnya proses pembelajaran sehingga proses pembelajaran tidak berjalan dengan baik. Menurut Cahyono, kesulitan belajar adalah suatu kondisi dalam pembelajaran yang ditandai oleh hambatan-hambatan tertentu untuk mencapai hasil belajar (Cahyono, 2019). 
Selain berdampak pada proses pembelajaran juga berdampak pada hasil belajar. Hal inilah yang membuat kualitas tidak sesuai dengan yang diinginkan oleh tujuan pembelajaran.

Universitas Samawa salah satu Lembaga Pendidikan Perguruan Tinggi di Sumbawa sudah menerapkan work from home sesuai aturan yang dikeluarkan pemerintah terkait pandemi covid 19. Berbagai strategi yang dilakukan dosen di Universitas Samawa khususnya Fakultas Keguruan dan Ilmu Pendidikan Program Studi Pendidikan Biologi melaksanakan pembelajaran secara online atau online learning. Pembelajaran online merupakan pembelajaran dengan memanfaatkan internet tanpa harus bertatap muka. Pembelajaran online merupakan salah satu inovasi pembelajaran dengan sifat dan karakteristik internet yang cukup khas, sehingga bisa digunakan sebagai media pembelajaran (Waryanto, 2016). Dengan menggunakan berbagai teknologi informasi yang memudahkan mahasiswa untuk tetap melaksanakan proses perkuliahan secara online, aplikasi yang digunakan sebagai media pembelajaran diantaranya; zoom meeting, google classroom, schology, whatsapp, Instagram, facebook, dan line. Melalui berbagai macam media pembelajaran ini pendidik dapat membuat kelas online.

Penggunaan teknologi informasi khususnya internet terus berkembang. Pengembangan Pendidikan menuju pembelajaran online merupakan suatu keharusan agar standar mutu Pendidikan menjadi lebih baik. Pembelajaran online adalah suatu sistem pembelajaran terbuka dan tersebar dengan menggunakan perangkat pedagogik, yang dimungkinkan melalui internet untuk memfasilitasi pembentukan proses pembelajran dan pengetahuan melalui aksi dan intraksi yang berarti (Dabbagh, 2005). Ada empat karakteristik penggunaan teknologi internet dalam penyampaian pembelajaran yaitu: 1) memanfaatkan komputer sebagai media pembelajaran. Pemebelajaran dalam kelas maupun luar kelas menggunakan teknologi elektronik, 2) memanfaatkan teknologi jaringan komputer, komputer didesain agar mahasiswa dan dosen dapat berintraksi, diharapkan dapat terjadi proses belajar mengajar seperti dalam kelas, 3) menggunakan bahan ajar bersifat mandiri disimpan dalam computer sehingga bisa di akses oleh dosen dan mahasiswa, 4) membutuhkan pembimbing salah satunya dalam hal pengoprasian media pembelajaran (Hamka, 2015).

Namun, dalam proses perkuliahan tanpa tatap muka atau secara online ini tidak memuaskan dan tentunya banyak kesulitan yang dihadapi oleh mahasiswa, hal ini terlihat dari ada beberapa mahasiswa yang tidak mengikuti proses perkuliahan sehingga pendidik tidak bisa memantau dan ini juga berdampak pada hasil belajar mahasiswa. Keberhasilan proses pembelajaran dapat dilihat dari prestasi belajar yang dicapai mahasiswa (Jirana, 2015). Hal ini menjadi dilema bagi pendidik untuk bisa melaksanakan perkuliahan secara online. Bila dibandingan dengan perkuliahan secara langsung hasil belajar mahasiswa lebih baik. Pendidik harus mampu membantu kesulitan-kesulitan yang dihadapi mahasiswa dalam proses pembelajaran (Rusman, 2010). Oleh sebab itu tujuan dari penelitian ini untuk menganalisis kesulitan proses pembelajaran online pada Mahasiswa Pendidikan Biologi Universitas Samawa di tengah pandemi covid 19. Melalui tulisan ini nantinya bisa menjadi referensi bagi dosen dalam menerapkan pembelajaran secara online untuk meminimalisir kesulitan yang dihadapi mahasiswa.

\section{Metode Penelitian}

Penelitian ini menggunakan metode kualitatif melalui pendekatan deskritif. Teknik pengambilan sampel menggunakan Teknik purposive sampling yaitu mengambil sampel dengan berdasar pada usaha pencapaian tujuan penelitian. Sampel penelitian yaitu mahasiswa Pendidkkan Biologi Universitas Samawa. Teknik pengumpulan data menggunakan kuisioner terkait mengenai kesulitan pembelajaran online yang diisi oleh responden. Keabsahan data dalam penelitian ini menggunakan triangulasi. Triangulasi adalah Teknik pemeriksaan keabsahan data yang memanfaatkan sesuatu yang lain di luar data sebagai pembanding. Pada penelitian ini penulis menggunakan triangulasi sumber yaitu dengan mengecek data dari beberapa sumber. Sedangkan untuk analisis data dalam penelitian ini menggunakan analisis data menggunakan model analisis data interaktif yaitu berdasarkan data yang diperoleh menurut Milles dan Huberman sebagai berikut: 1) Reduksi data, yang diartikan sebagai pemilihan, pemusatan perhatian pada penyederhanaan dan transformasi data kasar yang muncil dari catatan tetulis di lapangan; 2) Penyajian data, sekumpulan informasi informasi tersusun yang memberi adanya kemungkinan penarikan kesimpulandean pengambilan Tindakan; 3) Menarik kesimpulan, sebagaian dari satu kegiatan konfigurasi yang utuh. Kesimpulan juga diverifikasi selama penelitian berlangsung. Verifikasi yaitu pemikiran kembali atau tinjauan ulang dari catatan di lapangan. 


\section{Hasil Dan Pembahasan}

Data peneliti dikumpulkan melalui kuisioner dan studi dokumentasi, kemudian data tersebut di analisis secara deskriptif mengenai kusulitan dalam proses pembelajaran online mahasiswa Pendidikan Biologi Universitas Samawa.

Kriteria responden dalam penelitian ini adalah mahasiswa yang kuliah di program studi Pendidikan biologi dan yang ikut perkuliahan atau pembelajaran secara online. Dalam menganalisis data peneliti menggunakan beberapa aspek dalam kuisioner Melalui aspek yang digunakan ini dapat menjawab permasalahan yang terjadi yaitu mengenai kesulitan yang dihadapi oleh mahasiswa dalam proses pembelajaran online. Aspek yang dimaksud yaitu 1) Aplikasi yang digunakan dosen dalam proses pembelajaran secara online, 2) Proses pembelajaran online

Adapun kesimpulan dari hasil kuisioner yang diisi oleh responden terkait pembelajaran online sebagai berikut: 1) Aplikasi media pembelajaran online yang digunakan, rata-rata mahasiswa menjawab whatsapp, email, google classroom, zoom. Namun dari beberapa media tersebut yang paling sering digunakan whatsapp dan google classroom; 2) Penggunaan media pembelajaran oleh dosen dalam pembelajaran ini dari hasil kuisioner sebagai besar responden menjawab kesulitan karena membutuhkan jaringan internet dan kuota tinggi. Sedangkan mahasiswa banyak yang berada di daerah yang kurang jaringan internet, sehingga harus mencari jaringan internet yang kuat jauh dari rumah; 3) Media pembelajaran yang digunakan oleh dosen, mahasiswa selalu di pandu, sehingga tidak merasa kesulitan; 4) Sedangkan untuk mengakses materi yang diberikan oleh dosen, rata-rata mahasiswa tidak mearasa kesulitan, namun dosen jarang menjelaskan materi yang dibagikan kepada mahasiswa; 5) Strategi yang digunakan dosen dalam proses pembelajaran online, rata-rata mahasiswa menjawab strategi yang digunakan tidak bervariasi kebanyakan diberikan tugas; 6) Sedangkan untuk mata kuliah yang seharusnya menerapkan praktikum tidak terlaksana dan digantikan dengan pemberian tuigas terkait dengan materi praktikum; 7) Terkait dengan apakah pembelajaran online menyenangkan atau tidak, rata-rata mahasiswa menjawab tidak menyenangkan dan membosankan.

\section{Pembahasan}

\section{Aplikasi Media yang Digunakan Dosen Dalam Proses Pembelajaran Online}

Aplikasi merupakan perangkat lunak yang siap digunakan. Dalam proses pembelajaran online dosen di Program Studi Pendidikan Biologi menafaatkan berbagai jenis aplikasi diantaranya google classroom, zoom, whatsapp, email, facebook dan line. Dari berbagai jenis aplikasi tersebut yang dominan digunakan oleh dosen yaitu whatsapp, dan google classroom. Berdasarkan hasil kuisioner bahwa dari jawaban responden setelah disimpulkan menyatakan dari berbagai aplikasi yang digunakan dosen tidak ada yang rumit, namun mahasiswa terkendala dengan kuota dan jaringan internet. Kesulitan dari jaringan ini disebabkan kondisi wilayah belum seluruhnya memiliki jaringan internet kadang juga jaringan lelet karena rata-rata mahasiswa berada di daerah yang terpencil. Selain itu tentunya mahasiswa kesulitan ekonomi untuk mengisi kuota internet. Faktor pendukung pembelajaran menggunakan aplikasi berbasis internet salah satunya google classroom yaitu: kesiapan SDM untuk meningkatkan pembelajaran online, fasilitas sarana internet dan kebutuhan pelaksanaan media pembelajaran untuk meningkatkan aktivitas pembelajaran di kelas (Sabran, 2019). Hal ini sesuai dengan pernyataan Hamka bahwa faktor yang mempengaruhi penggunaan internet sebagai media pembelajaran dipetakan dalam dua kategori utama yaitu faktor sarana dan prasarana dan faktor sumber daya manusia (ekonomi) (Hamka, 2015). Dengan kondisi yang dihadapi negara akibat covid 19 ini banyak yang di PHK dan kesulitan masyarakat bekerja di luar rumah, sehingga penghasilan masyarakat berkurang dan ini berdampak pada ekonomi keluarga mahasiswa. Tentunya hal ini juga harus diperhatikan, sehingga nantinya proses pembelajaran tidak terhambat. Dalam melaksanakan pembelajaran online tentu harus diperhatikan masalah yang dihadapi seperti ketersediaan jaringan internet, listrik dan infrastruktur yang lainnya (Kusmana, 2011).

\section{Proses Pembelajaran Secara Online}

Dalam proses pembelajaran secara online ini sangat membantu bagi dosen dan mahasiswa dari segi waktu karena dapat dilakukan kapan saja dan dimana saja. Melalui aplikasi yang digunakan dalam pembelajaran mahasiswa dapat mengakses materi serta tugas yang diberikan oleh dosen. Namun jika matakuliah yang melaksanakan kegiatan praktikum tidak berjalan dengan baik. Berdasarkan hasil kuisioner bahwa matakuliah yang melaksanakan praktikum terkadang dosen menggantinya dengan tugas terkait materi praktikum dan ada 
juga yang memberikan petunjuk praktikum dan mahasiswa melaksanakan praktikum mandiri. Melalui pembelajaran online ini intraksi antara dosen dan mahasiswa kurang, baik dalam hal diskusi yang terjadi antara dosen dan mahasiswa, kemudian variasi dari strategi atau metode dalam proses pembelajaran kurang bervariasi karena dosen lebih banyak memberikan tugas, sehingga itu yang menjadi hambatan bagi mahasiswa dan menimbulkan rasa bosan dan ketidaktertarikan dengan proses pembelajaran online. Menurut Mariamah, bahwa dalam belajar harus disajikan secara tepat dan bervariasi agar tidak membosankan (Mariamah, 2015). Walaupun dosen menggunakan beberapa apliaksi sebagai media pembelajaran agar mahasiswa tidak jenuh atau bosan namun berdasarkan kuisioner bahwa mahasiswa merasa bosan dengan pembelajaran yang dilaksanakan secara online. Menurut Irawan perlunya metode pembelajaran yang dapat digunakan sebagai media pembelajaran online pendamping guru, baik yang bersifat visual, audio, maupun audio visual yang memudahkan untuk diakses (Yudie Irawan, 2015). Sedangkan menurut Sukardi (2019) pembelajaran online dapat berhasil dengan baik jika tutorial yang diberikan oleh guru memiliki kualitas yang baik.

Hal ini juga karena di pengaruhi kesulitan dari mahsiswa mendapatkan jaringan internet, yang mengharuskan mahsiswa mendapat jaringan di daerah yang jaraknya cukup jauh dengan rumah. Adanya rasa bosan dan ketidaktertarikan mahasiswa terhadap proses pembelajaran berdampak pada minat belajar mahasiswa. Misalnya kurang aktif dalam diskusi melalui media pembelajaran, tidak mengerjakan tugas yang diberikan oleh dosen. Sehingga berdampaklah pada hasil belajar dari mahasiswa. Minat belajar adalah rasa tertarik atau kecendrungan melakukan suatu kegiatan untuk memperoleh suatu pengetahuan atau perubahan perilaku sebagai hasil pengalamanya sendiri (Suciyati, 2018). Sedangkan menurut Rahmadani bahwa minat yang rendah menyebabkan kesulitan belajar pada diri seseorang (Rahmadani, 2017). Jadi minat belajar merupakan salah satu faktor penyebab dari kesulitan belajar.

\section{Simpulan}

Berdasarkan hasil penelitian bahwa kesulitan mahasiswa dalam melaksanakan proses pembelajaran di tengah pandemi covid 19 disebabkan oleh beberapa faktor yaitu sarana prasarana terutama jaringan internet dan sumber daya manusia (ekonomi) yang merupakan faktor eksternal dan faktor internal yang berupa minat mahasiswa. Perlunya mengkaji efektifitas dari berbagai aplikasi media pembelajaran sehingga dosen dapat menggunakan media yang tepat untuk proses pembelajaran online.

\section{Ucapan Terima Kasih}

Sebagai ucapan terima kasih terlaksananya kegiatan penelitian ini, penulis mengucapkan terima kasih kepada Dekan Fakultas Kegutuan Dan Ilmu Pendidikan yang telah memberikan ijin dalam melaksanakan penelitian serta mahasiswa Pendidikan Biologi Universitas Samawa yang telah membantu dalam mendapatkan data sebagai kajian dalam penelitian ini.

\section{Daftar Pustaka}

Cahyono, H. (2019). Faktor-faktor Kesulitan Belajar Siswa MIN JANTI. Jurnal Dimensi Pendidikan dan Pembelajaran, 1-4.

Dabbagh, N. d. (2005). Online Learning, Concepts, Strategies And Application. Ohio: Person.

Hamka. (2015). penggunaan internet sebagai media pembelajaran pada mahasiswa IAIN Palu. Studia Islamika, 98-119.

Jirana, N. S. (2015). faktor-faktor yang mempengaruhi kesulitan dan minat belajar mahasiswa jurusan Pendidikan Biologi Universitas Sulawesi Barat. Saintifik, 87-94.

Kusmana, A. (2011). E-learning dalam Pembelajaran . Lentera Pendidikan, 35-51.

Mariamah, N. D. (2015). pengembangan buku ajar mata kuliah teori bilangan pada mahasiswa semester IIIjurusan pendidikan matematika STKIP Taman Siswa Bima tahun akademi 2014/2015. pendidikan MIPA , 1-12.

Musliansani. (2018). sistem pakar untuk pemilihan program studi pada perguruan tinggi berbasis web. Penndidikan MIPA, 112-115. 
rahmadani, w. (2017). analisis faktor belajar biologi siswa materi bioteknologi di SMA Negeri se-kota Medan. Pendidikan Biologi, 279-285.

Rusman. (2010). model-model pembelajaran pengembangan profesionalisme guru. jakarta: Rajawali Press.

Sabran, e. s. (2019). keefektifan google classroom sebagai media pembelajaran. diseminasi hasil penelitian melalui optimalisasi sinta dan hak kekayaan intelektual, pp. 122-125.

Suciyati, M. (2018). Hubungan Minat Belajar dengan Hasil Belajar Matematika pada Siswa Kelas V SD Negeri 04 Sila. Pendidikan MIPA, 142-149.

Sukardi, F. R. (2019). Pengaruh Model Pembelajaran Online Dilengkapi dengan Tutorial Terhadap Hasil Belajar. Jurnal Ilmiah Pendidikan dan Pembelajaran Informatika (JIPI), 97-102.

waryanto. (2016). on-line learning salah satu inovasi pembelajaran . phytagoras, 10-23.

Yudie Irawan, N. W. (2015). Analisis dan perencanaan sistem pembelajaran online (E-learning) pada SMAK Mambaul Falah Kudus. Simetris, 345-352.

Yuliana. (2020). Corona Virus Diseases (Covid-19); Sebuah Tinjauan Literatur. Wellness And Healthy Magazine, 187-192. 